\title{
MYELITIS DUE TO VACCINATION
}

Myelitis as part of a post vaccinial encephalomyelitis is well known, and histological changes occurring in the spinal cord were fully described in the earlier case records (Turnbull and McIntosh, 1926). The purpose of the present paper is to draw attention to the fact that myelitis uncomplicated by encephalitis also occurs as a sequel to vaccination. The following case which I have recently had the opportunity of observing is typical of this group.

An R.A.F. recruit, aged 27 , received his primary vaccination 3rd September, 1942, over the left deltoid, and at the same time received an injection of 0.25 c.c. of T.A.B. and $1 \mathrm{cc}$. of A.T.T. vaccines in the right arm. On the 12th he received a second injection of 0.5 c.c. of T.A.B. He sweated that night and felt feverish, suffered from stabbing pains in the arms, especially at site of vaccination: the pains persisted for some days. As they passed off he developed pain in his calves and feet, and noticed that his legs were not properly under control. He did not report sick till the tenth day of his illness when he fell on parade. He was admitted to Station Sick Quarters, where he was found to be feverish. The fever continued for four or five days, pain and weakness of his legs was more persistent, but a full neurological examination soon after admission to Sick Quarters is reported to have revealed no objective signs. He was discharged from Sick Quarters after seventeen days illness and did light duty for five days, then on the 5 th of October, on getting out of bed, he found that his legs were stiff and wobbly and he had no control of his bladder. The condition appears to have been progressive, incontinence becoming complete the next day, and by the twenty-third day of his illness he was completely paralysed from the waist down, with complete sensory loss to the costal margin, absent tendon jerks and plantar withdrawal responses. A lumbar puncture on this day showed a pressure of $170 \mathrm{~mm}$. of fluid, a pleocytosis of 1,500 lymphocytes per cubic $\mathrm{mm}$. and protein 80 mgm. per cent. Five days later it was noticed that the anæsthesia was receding and in another five days some voluntary movement had returned to the toes. Three deep bedsores and urinary infection had unfortunately developed.

Cutaneous sensation was almost completely restored by the 45th day. By January, 1943, approximately 15 weeks after first symptoms, there was sufficient power in all muscular groups to allow movement against gravity at all joints, but the legs were not sufficiently strong to support the patient. The paralysed muscles were now flaccid, the tendon jerks were just obtainable, the plantars were extensor and control of the sphincters had been regained.

Motor power continued to return and he was taught to walk, first supported under the armpits by a machine and later with two sticks in his hands.

In June, 1943 the bedsores were almost completely healed and the patient could, with one stick, walk up to two miles.
BY.

\section{DIXON}

OCTOBER, 1943)

On examination there was very little demonstrable muscular weakness, no abnormality of tendon jerks, tone or sensation, though the plantars remained extensor.

The case here described resembles the original 47 cases of post vaccinial encephalitis selected by the Andrews Committee (Vacc., 1928) in being febrile and in occurring within the 2nd to 24th day after vaccination; like the majority, the vaccination was the primary one and like five of the said group, the illness occurred on the 9th day after vaccination; and resembles the majority of the non-fatal cases in the completeness of its recovery.

The increase of protein and leucocytosis are also common features in post vaccinial encephalomyelitis (Vac., 1930). It differs, however, markedly from the 47 classical cases, in that the symptoms were spinal rather than cerebral and there was no headache, vomiting, strabismus or clouding of consciousness.

An almost identical case is described by Gounelle (1931) (see Table). This case, also a young soldier, had a partial remission, and paraplegia developed suddenly on the 13th day of his illness. Such a remission in the course of post-vaccinial encephalomyelitis is not an unusual finding and is in fact described in the first published case (Comby, 1907).

I have been able to trace twelve other cases of myelitis following vaccination within the 3 rd to 15 th day.

Two of these occurred among the original 63 cases considered by the Andrews Committee (May, 1925) and a further 2 among the 44 cases submitted following Committee's request for further information in the medical press April, 1926. At the time of the publication of the Ministry of Health report on vaccination 1928, these cases of uncomplicated myelitis were not thought to be due to vaccination. In a further report, November, 1930, the Committee describe 3 cases of uncomplicated myelitis among 90 cases of post-vaccinial encephalomyelitis. One of this group is of especial interest as the patient (see Table, 1930, "case 148 ") died of urinary infection on the 94th day and at autopsy the histology of the nervous system was described "In the pons and spinal cord there are perivascular and marginal areas of demyelination such as are found in post vaccinial encephalomyelitis. The lesions have reached the stage at which fat-granule cells are very abundant (M.M.T.)." 
Tabulated findings of Previously Published Cases of Myelitis following Vaccination

\begin{tabular}{|c|c|c|c|c|c|}
\hline Date and Author & Patient & Incubation & Onset & Physical signs & Progress and result \\
\hline 1943 & $\begin{array}{c}\text { Male, } \\
\text { aged } 27\end{array}$ & $\begin{array}{l}9 \text { th or } 10 \text { th day } \\
\text { after primary } \\
\text { vaccination }\end{array}$ & $\begin{array}{l}\text { Pyrexia, muscular } \\
\text { pains, unsteadiness } \\
\text { of legs for } 17 \text { days. } \\
\text { Partial remission; } \\
23 \text { rd day sudden } \\
\text { paraplegia and in- } \\
\text { continence. }\end{array}$ & $\begin{array}{l}\text { Flaccid paralysis of } \\
\text { legs and analgesia } \\
\text { below seg. } \\
\text { C.S.F. 25th day } \\
\text { protein } 0.08 \text { per } \\
\text { cent.; } 1,500 \text { lym- } \\
\text { phocytes per c.mm. }\end{array}$ & $\begin{array}{l}\text { Gradual recession of } \\
\text { level of anæsthesia, } \\
\text { sensation normal in } \\
45 \text { days. Return of } \\
\text { motor power in } 5 \\
\text { months; persistent } \\
\text { extensor plantars. }\end{array}$ \\
\hline $\begin{array}{c}1942 \\
\text { Anderson and } \\
\text { McKenzie, } \\
\text { Case } 7\end{array}$ & $\begin{array}{l}\text { Male, } \\
\text { aged } 16\end{array}$ & $\begin{array}{l}\text { 14th day after } \\
\text { primary } \\
\text { vaccination }\end{array}$ & $\begin{array}{l}\text { Retension of urine } \\
\text { and signs of trans- } \\
\text { verse myelitis in } \\
\text { thoracic region. }\end{array}$ & - & Recovered. \\
\hline $\begin{array}{c}1937 \\
\text { Clouston and } \\
\text { Quins }\end{array}$ & $\begin{array}{c}\text { Female, } \\
\text { aged } 9\end{array}$ & $\begin{array}{l}\text { 5th day after } \\
\text { vaccination }\end{array}$ & $\begin{array}{l}\text { Fever and pain in } \\
\text { neck for } 2 \text { days, } \\
\text { weakness of legs, } \\
\text { retention of urine. } \\
\text { 3rd day paralysis of } \\
\text { legs. }\end{array}$ & $\begin{array}{l}\text { Flaccid paralysis and } \\
\text { sensory loss below } \\
\text { seg. } 6 \text { D. C.S.F. on } \\
\text { 4th day } 5 \text { lympho- } \\
\text { cytes. No globulin. }\end{array}$ & $\begin{array}{l}\text { Gradual recession of } \\
\text { level of anæsthesia } \\
\text { starting on 5th day. } \\
\text { Gradual return of } \\
\text { motor power, in } 5 \\
\text { months normal ex- } \\
\text { cept for exaggerated } \\
\text { reflexes. }\end{array}$ \\
\hline $\begin{array}{c}1932 \\
\text { Paulian, Aricesco } \\
\text { and Finkelstein }\end{array}$ & $\begin{array}{l}\text { Female, } \\
\text { aged } 7\end{array}$ & $\begin{array}{l}\text { 3rd day after } \\
\text { 1st re- } \\
\text { vaccination }\end{array}$ & $\begin{array}{l}3 \text { days fever two days } \\
\text { after vaccination. } \\
\text { Two weeks later } \\
\text { pains in calves, un- } \\
\text { able to walk. Re- } \\
\text { tention of urine. } \\
\text { Attitude of flexion. }\end{array}$ & $\begin{array}{l}\text { After an interval of } \\
\text { less than } 6 \text { months } \\
\text { spastic palsy in } \\
\text { flexion of arms and } \\
\text { legs with muscular } \\
\text { wasting and no } \\
\text { sensory changes. }\end{array}$ & $\begin{array}{l}\text { Recovered power of } \\
\text { walking during a } 1- \\
\text { month period of ob- } \\
\text { servation though } \\
\text { obvious quadra- } \\
\text { plegia persisted. }\end{array}$ \\
\hline $\begin{array}{c}1931 \\
\text { Gounelle }\end{array}$ & $\begin{array}{l}\text { Male, } \\
\text { aged } 21\end{array}$ & $\begin{array}{c}\text { 14th day after } \\
\text { Ist } \\
\text { vaccination }\end{array}$ & $\begin{array}{l}7 \text { days' fever, un- } \\
\text { steadiness of legs. } \\
\text { Positive Rhomberg's } \\
\text { signs and brisk knee } \\
\text { and ankle jerks. } \\
\text { Partial recovery; } \\
\text { 13th day sudden } \\
\text { paraplegia and re- } \\
\text { tention of urine. }\end{array}$ & $\begin{array}{l}\text { No notes on sensory } \\
\text { findings or exact } \\
\text { level of palsy. } \\
\text { C.S.F. on 5th day } \\
\text { protein } 0.056 \text { per } \\
\text { cent. } 25 \text { lympho- } \\
\text { cytes per c.mm. } \\
\text { Muscular fib. ob- } \\
\text { served in acute } \\
\text { phase. }\end{array}$ & $\begin{array}{l}\text { Rapid recovery in one } \\
\text { month. Able to re- } \\
\text { turn to work. }\end{array}$ \\
\hline $\begin{array}{c}1931 \\
\text { Brockbank }\end{array}$ & $\begin{array}{l}\text { Male, } \\
\text { aged } 6\end{array}$ & $\begin{array}{l}\text { 14th day after } \\
\text { vaccination }\end{array}$ & $\begin{array}{l}\text { One week's fever } \\
\text { with sudden para- } \\
\text { lysis of legs and } \\
\text { retention of urine, } \\
\text { anæsthesia to be- } \\
\text { low seg. } 7 \text { D. on } \\
\text { 2nd day. Spread } \\
\text { of anæsthesia to } \\
\text { seg. } 3 \mathrm{D} \text {. }\end{array}$ & $\begin{array}{l}\text { Flaccid paraplegia } \\
\text { and doubtful weak- } \\
\text { ness of left arm and } \\
\text { anæsthesia. C.S.F. } \\
\text { on date unknown } \\
\text { pressure } 160 \mathrm{~mm} \text {. } \\
50 \text { cells per c.mm. } \\
\text { and Globulin }++\end{array}$ & $\begin{array}{l}\text { Gradual recession of } \\
\text { level of anæsthesia. } \\
\text { No further recovery } \\
\text { in subsequent } 6 \\
\text { months. }\end{array}$ \\
\hline $\begin{array}{c}1929 \\
\text { Peake }\end{array}$ & $\begin{array}{l}\text { Female, } \\
\text { aged } 8\end{array}$ & $\begin{array}{l}\text { 8th day after } \\
\text { revaccination }\end{array}$ & $\begin{array}{l}\text { Fever and pains in } \\
\text { abdomen. 4th day } \\
\text { became drowsy and } \\
\text { had retention of } \\
\text { urine. 7th day para- } \\
\text { plegia discovered. }\end{array}$ & $\begin{array}{l}\text { 7th day flaccid para- } \\
\text { plegia and anæs- } \\
\text { thesia to umbilical } \\
\text { level. Fever per- } \\
\text { sisted about } 3 \text { weeks } \\
\text { due to urinary in- } \\
\text { fection. }\end{array}$ & $\begin{array}{l}\text { Gradual recession of } \\
\text { level of anæsthesia. } \\
\text { Sensation normal } \\
50 \text { th day, able to } \\
\text { walk with slight sup- } \\
\text { port on both sides } \\
\text { and partial recovery } \\
\text { of sphincters in } 3 \\
\text { months. } \\
\text { * Complete recovery } \\
\text { in } 6 \text { months. }\end{array}$ \\
\hline $\begin{array}{c}1930 \\
\text { Further report } \\
\text { of Committee on } \\
\text { Vaccination, } \\
\text { Case 148 }\end{array}$ & $\begin{array}{l}\text { Female, } \\
\text { aged } 46\end{array}$ & $\begin{array}{l}13 \text { th day after } \\
\text { revaccination }\end{array}$ & $\begin{array}{l}\text { Fever and pricking } \\
\text { sensation in legs; } \\
\text { 3rd day motor and } \\
\text { sensory paraplegia } \\
\text { and disturbance of } \\
\text { sphincters. }\end{array}$ & $\begin{array}{l}\text { Flaccid paraplegia to } \\
\text { level of higher thor- } \\
\text { acic segments. Hist- } \\
\text { ology, see text. }\end{array}$ & $\begin{array}{l}\text { Death from urinary } \\
\text { infection on 94th } \\
\text { day. Some evidence } \\
\text { of returning of func- } \\
\text { tions of cord as } \\
\text { sphincter control was } \\
\text { regained b e f o r e } \\
\text { death. Autopsy. }\end{array}$ \\
\hline
\end{tabular}


TABLE I-continued

\begin{tabular}{|c|c|c|c|c|c|}
\hline Date and Author & Patient & Incubation & Onset & Physical signs & Progress and result \\
\hline $\begin{array}{c}1930 \\
\text { Further report of } \\
\text { Committee on } \\
\text { Vaccination, } \\
\text { Case } 85\end{array}$ & $\begin{array}{l}\text { Female, } \\
\text { aged } 19\end{array}$ & $\begin{array}{l}\text { 10th day after } \\
\text { primary } \\
\text { vaccination }\end{array}$ & $\begin{array}{l}\text { Headache, vomiting, } \\
\text { loss of power in } \\
\text { legs and retention } \\
\text { of urine. }\end{array}$ & $\begin{array}{l}\text { Considered doubtful. } \\
\text { Hysteria suggested } \\
\text { as diagnosis. }\end{array}$ & $\begin{array}{l}\text { Uneventful recovery } \\
\text { in } 18 \text { days. }\end{array}$ \\
\hline $\begin{array}{l}1930 \\
\text { Further report of } \\
\text { Committee on } \\
\text { Vaccination, } \\
\text { Case } 90\end{array}$ & $\begin{array}{l}\text { Female, } \\
\text { aged } 12\end{array}$ & $\begin{array}{l}\text { 8th day after } \\
\text { primary } \\
\text { vaccination }\end{array}$ & $\begin{array}{l}\text { "Transient } \\
\text { Myelitis " }\end{array}$ & - & $\begin{array}{l}\text { Recovery after } 20 \\
\text { days. }\end{array}$ \\
\hline $\begin{array}{l}1928 \\
\text { Further report of } \\
\text { Committee on } \\
\text { Vaccination, } \\
\text { Case } 10\end{array}$ & $\begin{array}{l}\text { Female, } \\
\text { aged } 3 \\
\text { months }\end{array}$ & $\begin{array}{l}15 \text { th day after } \\
\text { primary } \\
\text { vaccination }\end{array}$ & $\begin{array}{l}\text { On or about } 10 / 2 / 26 \\
\text { developed paresis of } \\
\text { both legs. }\end{array}$ & $\begin{array}{l}\text { Positive W.R. in } \\
\text { child's and mother's } \\
\text { blood. Father's } \\
\text { blood negative. }\end{array}$ & - \\
\hline $\begin{array}{l}1928 \\
\text { Further report of } \\
\text { Committee on } \\
\text { Vaccination, } \\
\text { Case } 28\end{array}$ & $\begin{array}{l}\text { Female, } \\
\text { aged } 15\end{array}$ & $\begin{array}{l}7 \text { th day after } \\
\text { vaccination }\end{array}$ & $\begin{array}{l}\text { Headache and pains } \\
\text { in all four limbs. } \\
\text { 3rd day rigor, de- } \\
\text { lirium. High fever. } \\
\text { Lost use of all } 4 \\
\text { limbs. }\end{array}$ & $\begin{array}{l}\text { 13th day spastic } \\
\text { paresis of arms. } \\
\text { Flaccid paresis of } \\
\text { legs. Retention of } \\
\text { urine. No sensory } \\
\text { changes. }\end{array}$ & $\begin{array}{l}\text { Progressive motor re-- } \\
\text { covery. Intermittent } \\
\text { fever and persistent } \\
\text { bed sores. Death } \\
118 \text { th day. }\end{array}$ \\
\hline $\begin{array}{l}1925 \\
\text { Andrew's } \\
\text { Committee, } \\
\text { Case } 5\end{array}$ & $\begin{array}{l}\text { Female, } \\
\text { aged } 13\end{array}$ & $\begin{array}{l}11 \text { th day after } \\
\text { vaccination }\end{array}$ & $\begin{array}{l}\text { Pain in back, head- } \\
\text { ache, vomiting, rash } \\
\text { and paraplegia. }\end{array}$ & 一 & Death on 164th day. \\
\hline $\begin{array}{c}1925 \\
\text { Andrew's } \\
\text { Committee, } \\
\text { Case } 42\end{array}$ & $\begin{array}{l}\text { Male, } \\
\text { aged } 20\end{array}$ & $\begin{array}{l}\text { 12th day after } \\
\text { vaccination }\end{array}$ & $\begin{array}{l}\text { Retention of urine, } \\
\text { girdle pain in upper } \\
\text { dorsal region. } \mathrm{Pa}- \\
\text { resis and loss of } \\
\text { sensation below. }\end{array}$ & $\begin{array}{l}\text { Babinski's sign and } \\
\text { knee jerks. }\end{array}$ & Died. \\
\hline
\end{tabular}

The details of the other two are scanty, probably because they recovered; doubt is thrown on the diagnosis of at least one.

Six other cases have been published by different authors all of which (see Table) have a close similarity to the case here described.

It is, of course, open to argument that the case here described was caused like that of Gayle and Bowen (1933) by typhoid inoculation, but as these authors point out " such complications are certainly rare" and the disease in the cases they review takes the form of a peripheral neuritis, which sometimes extends into the spinal cord and medulla.

\section{Summary}

A case of a young man developing fever, muscular pains and unsteadiness of gait 9 days after primary vaccination, followed by a temporary remission and then a sudden paraplegia on the 23rd day is described. During the subsequent 6 months the patient almost completely recovered. The histories of 13 previously published cases of transverse myelitis occurring between the 3rd and 15th day after vaccination are summarized. Cerebral symp- toms indicative of an accompanying encephalitis only occurred in the acute phase of 3 of these cases and even then were overshadowed by the symptoms related to disease in the spinal cord.

I wish to express my thanks to Dr. Fergus R. Ferguson for his help and advice in treatment of this case and to Dr. Joseph Doupe for his help with this paper.

\section{REFERENCES}

Anderson, T., and McKenzie, P. (1942). Lancet, 243, 667.

Brockbank, T. W. (1931). J. Amer. med. Ass., 97, 227.

Clouston, T. M., and Quin, B. H. (1937). Med. J. Austr., 2, 568.

Comby, J. (1907). Arch. Méd. Enf., 10, 598.

Gayle, R. F., and Bowen, R. A. (1933). J. nerv. ment. Dis., 78, 221.

Gounelle, H. (1931). Paris méd., 2, 144.

Paulian, D., Aricesco, C., and Finkelstein, M. (1932). Bull. Soc. méd. Hôp., Paris, 48, 237.

Peake, H. G. (1929). J. roy. Army med. Corps, 94, 793. Turnbull, H. M., and McIntosh, J. (1926). Brit. J. exp. Path., 7, 181.

Vaccination. Ministry of Health report of Committee on 1928.

Vaccination. Ministry of Health further report of Committee on 1930. 